University of New Hampshire

University of New Hampshire Scholars' Repository

$1-2018$

\title{
Work of a Nation: Christian Funerary Ecumenism and Institutional Disruption in Swaziland
}

\author{
Casey Golomski \\ University of New Hampshire, Durham, casey.golomski@unh.edu
}

Follow this and additional works at: https://scholars.unh.edu/anth_facpub

\section{Comments}

This is an Author's Original Manuscript an article to be published by Taylor \& Francis in Journal of Southern African

Studies in 2018, available online: https://doi.org/10.1080/03057070.2018.1421443

\section{Recommended Citation}

Casey Golomski (2018) Work of a Nation: Christian Funerary Ecumenism and Institutional Disruption in Swaziland, Journal of Southern African Studies, 44:2, 299-314, DOI: 10.1080/03057070.2018.1421443

This Article is brought to you for free and open access by the Anthropology at University of New Hampshire Scholars' Repository. It has been accepted for inclusion in Anthropology Scholarship by an authorized administrator of University of New Hampshire Scholars' Repository. For more information, please contact Scholarly.Communication@unh.edu. 
7 December 2016

\section{Journal of Southern African Studies}

Special issue 'Grassroots Ecumenism in Conflict', Richard Werbner and Anthony Simpson, eds.

Article Title:

'Work of a Nation: Christian Funerary Ecumenism and Institutional Disruption in Swaziland'

\section{Article Author:}

Casey Golomski

University of New Hampshire

Department of Anthropology

310 Huddleston Hall

73 Main Street

Durham, NH 03824

Author Bio:

Casey Golomski is Assistant Professor in the Department of Anthropology at the University of New Hampshire and an associate with the Life Course, Obligation, and Dependency (LOAD) research unit at the University of the Witwatersrand. His related research on religion and issues of organisational and sociopolitical life in Southern Africa has appeared in Journal of Contemporary Religion, African Studies, African Journal of AIDS Research, and Material Religion.

\section{Article Title}

'Work of a Nation: Christian Funerary Ecumenism and Institutional Disruption in Swaziland' 1

\section{Article Abstract}

This article traces how contemporary funerary practices-foodways, prayer and burial cooperative participation - configure a Christian public culture in Swaziland that draws from ordinary citizens' religious, ritual and political work and membership in diverse Christian churches. This kind of grassroots ecumenism importantly challenges the potency of orthodox institutional ecumenical projects of religious elites in the Kingdom. These projects include attempts to legislate Christianity as an official religion and the building of a national interdenominational church, both of which have failed to materialise. Exploring this emergent tension between religious institutions' ideological goals versus communities' practical engagement on pressing social problems invites a rethinking of how citizens produce public cultures. Research is based on intermittent fieldwork at funerals, burial cooperatives, family ceremonies, and churches, interviews with local church leaders and theologians, and document research in Swaziland from 2008 to 2015.

\footnotetext{
${ }^{1}$ Encouragement, comments, and insights I garnered while writing the different sections of this article came from Richard Werbner, Sonene Nyawo, Joel Cabrita, Jessica A. Hardin, S.T. Lukhele, Nhlanhla C. Dlamini, R. Simangaliso Kumalo, Martha Shongwe, Hebron Luhlanya Ndlovu, Britt Halvorson, Caitrin Lynch, Maruta Vitols, Birgit Meyer, Joseph B. Hill, Mara Leichtman, and Hylton White. Research was made possible by Fulbright IIE, Andrew W. Mellon Foundation, Brandeis University's Department of Anthropology and Graduate School of Arts and Sciences, and the University Research Council at the University of the Witwatersrand.
} 


\section{INTRODUCTION}

The day I arrived in August 2010 to begin a year of field research was the day a national ecumenical organisation, the Swaziland Conference of Churches (SCC), denounced the fried chicken restaurant KFC. SCC, a group of mission derived Protestant evangelical churches and the oldest ecumenical organisation in the Kingdom, led by President Bishop Steven Masilela, condemned KFC as 'food sacrificed to idols' given that its franchise owners vended halaal products. Two years earlier in 2008, the Swaziland Halaal Authority (SHA) met KFC franchisees to negotiate for the iconic crescent star's use in packaging as Muslim customers were uncertain about the food's holy status. KFC chicken is sourced from Swazi Poultry Processors in Matsapha. Then franchise owner Mario Pimenta, a Catholic, explained to the Swazi Times, 'if the government of Swaziland accepts the Islamic faith, then it follows that our products have to also accommodate Muslims. KFC is just meat and has nothing to do with religion.'2

Some Christians, however, did not take this strict market approach to heart. Following negotiations with SHA, a halaal-branding initiative began in July 2010 that opened a barrage of criticism from several Christian organisations, including SCC. Masilela convened a meeting with KFC stakeholders leading to a short-term suspension of halaal meal sales. KFC then launched a local public relations campaign where customers could win a car if they correctly noted in their write-in submissions whether or not the restaurant served halaal. Masilela criticised the franchisees, saying, 'We cannot eat food that is sacrificed to other gods... there are some product[s], stamped halaal, but have not undergone the rituals. At times it is done as a marketing strategy in a bid to be leading products.' He urged 'Christians to always be on the lookout for things,' like halaal chicken, 'that may disturb their spirituality.' ${ }^{3}$

Public outcry was noticeable, not least of all the chatting crowds outside of the then relatively empty KFC on Ngwane Street near the Manzini bus rank market. Yet a more cautious Christian contingent leveled a public counterpoint statement shortly after the SCC. The ecumenical organisation the Swaziland Christian Churches United in Christ (SCCUC) noted that KFC's 'stakeholders made a commitment to protect Christians' right to freedom of choice.' 'Pastor Joseph Mudzingwa of the Seventh Day Adventists said as long as the individual Christian's conscience was clean, ${ }^{5}$ and even if one carefully assessed the choices, one might still willfully eat halaal. KFC quietly reintroduced halaal branding in its stores over the next few months after public scrutiny faded.

What was clear in this case of KFC was that popular Christian religious practice and opinion surrounding the affair was not only political, but not uniform across churches, representing a challenge to some orthodox ecumenical institutions' ability to cohere a singular organisational perspective or opinion on behalf of all self-identified Christians. At the intersection of religious social organisation and economy, business owners wanted to please the majority of their godly-inspired market to keep consuming the popular food. The restaurant, and by proxy Islam became the target of a public Christian religious gaze, and though powerful, this gaze was disrupted by real institutional-denominational and ideological differences among churches.

\footnotetext{
${ }^{2}$ T. Simelane, 'Your KFC is Now Halaal', Swazi Times (2010) July 5; T. Simelane, 'Your Nando's is Also Halaal', Swazi Times (2010) July 19; M. Terdiman, 'Islam in Swaziland', Research on Islam and Muslims in Africa Occasional Papers 1, 1 (2013) available at https://muslimsinafrica.wordpress.com/2013/02/14/islam-in-swaziland/, retrieved 10 November 2016. ${ }^{3}$ L. Jele, 'Christians Cannot Be Forced to Eat Halaal', Times of Swaziland (2010) August 26, p. 18.

${ }^{4}$ L. Jele, 'Christians Cannot Be Forced to Eat Halaal.'

${ }^{5}$ T. Simelane, 'Your KFC is Now Halaal.'
} 
Leading from this example of Christian institutional non-uniformity, this article demonstrates how other contemporary collective Christian religious practices - namely funerary foodways, prayer and burial cooperative participation-have more public cultural appeal. By and large, these are practices have come to preoccupy majority citizens' everyday lives in the wake of the world's worst HIV/AIDS epidemic. ${ }^{6}$ These popular practices embody a 'Christian public' ${ }^{7}$ that disrupts orthodox ecumenical institutions and movements and challenges us to rethink presumed 'models of resistance against political authority' in Southern Africa ${ }^{8}$ because they are born from citizens' membership in diverse church entities and faith-based organizations. I take these practices to be 'grassroots' ecumenical phenomena given their inter-denominational and relatively non-institutional character. They are public practices that people from distinct churches with distinct worship practices invest themselves in cooperatively to also shore up Christianity as a unifying ethical and ethno-national ethos, one though that is not necessarily tied to the state. What makes this kind of phenomena distinct and useful for interrogating politics in Southern Africa is that their performances and the ethos it engenders are driven by non-institutionalised concerns - everyday practices of the social majority accommodating dying, healing, living, and getting by amid generalised socioeconomic precarity.

Religious practices like these have groundswell popularity-or rather, are of immanent necessity given that they are also deathways - and can be of considerable political value to social and economic elites. Popular religion gains public appeal through the charisma of its leaders and in its ideological messages and or proposed answers in the face of change and uncertainty, and social and economic elites have stakes in trying capitalise on popular religion in patently institutional ways so as to effectively govern populations as part of modern state building. In postcolonial Africa, elites have often played with or preyed upon cultural or religious forms they deem 'indigenous' or 'traditional' to shore up popular political sentiments. ${ }^{9}$ This article discusses how this instead unfolds around Christian rather than 'traditional' religion, and specifically looks at attempts to consolidate aspects of popular religious practice into institutionally orthodox ecumenical forms. I discuss the parliamentary attempts to declare Swaziland an official Christian nation and attempts by the country's governing ecumenical bodies, including SCC and SCCUC, to build a new national interdenominational Christian church. In line with our aims in this Special Issue, this case from Swaziland demonstrates how a diverse social majority reconfigures religion as a public. In

\footnotetext{
${ }^{6}$ Since 2007 at least, Swaziland has harboured the world's highest HIV prevalence, with mortality rates breaching humanitarian emergency level thresholds in some regions prior to the national rollout of antiretroviral medication in the mid 2000s. G. Bicego, R. Nkambule, I. Peterson, et al. 'Recent Patterns in Population-Based HIV Prevalence in Swaziland', PLoS One 8, 10 (2013), e77101.

${ }^{7}$ By invoking 'Christian publics' in a discussion of ecumenism, I am expanding the possibilities of Harri Englund's use of the term. He notes a 'plurality of Pentecostal publics' and the 'sheer diversity' in these churches' expansion, the concept of ecumenism does not appear in his important volume. H. Englund, 'Introduction: Rethinking African Christianities', in H. Englund (ed), Christianity and Public Culture in Africa (Athens, OH: Ohio University Press, 2011), pp. 15-16; T.O. Ranger (ed), Evangelical Christianity and Democracy in Africa (Oxford: Oxford University Press, 2008).

${ }^{8}$ Englund, 'Introduction', p. 11.

${ }^{9}$ See, for example: S. Leclerc-Madlala, 'Virginity Testing', Medical Anthropology Quarterly 15, 4 (2001), pp. 533-552; B. de Robillard, “'Girls” and Virginity', Agenda 23, 79 (2011), pp. 85-93; H.L. Ndlovu, 'The Royal Easter Ritual and Political Action in Swaziland' (PhD thesis, McMaster University, 1993); H.L. Ndlovu, 'The Swazi Dual Monarchy', BOLESWA Journal of Theology, Religion and Philosophy 1, 3 (2007), pp. 116-134; R. Reis, 'Medical Pluralism and the Bounding of Traditional Healing in Swaziland', in W. Ernst (ed), Plural Medicine, Tradition and Modernity, 18002000 (New York: Routledge, 2002), pp. 95-112; B. Forrester and V. Laterza, Development in Swaziland (Pretoria: Sahee Foundation, 2014).
} 
assertions of morality and power, religion is drawn up and conscripted as a distinctive entity. Perhaps the most important problem for analysis is how that social majority negotiates this dynamic as means for popular co-operation and inclusion, and for giving and sharing across sociocultural boundaries.

Topically, this approach also goes to the heart of what Bennetta Jules-Rosette characterises as 'grass-roots ecumenism.' Jules-Rosette defines grass-roots ecumenism as a pragmatic process of sharing religious doctrine across churches, a process unfolding 'without an express design or a particular organisational structure to facilitate it. ${ }^{10}$ She found in her case study of the Masowe and Maranke churches ${ }^{11}$ in urbanising Lusaka, Zambia that 'crisis and conflict situations within the community provide motivating conditions for the religious as well as the practical resolution of problems. Under such conditions, groups that are doctrinally close join together in religious union.' ${ }^{12}$ Jules-Rosette shows how these organisations' relationships are 'asymmetrical' ${ }^{13}$ or hierarchical, yet interdependent in a broader socio-economic milieu: the poorer Maranke church members found work in Masowe church members' businesses and churches participated in joint ceremonies where each shared in the other's rites. In one case of a funeral, 'members of both groups valued their close mutual examination' of each other's rites, and 'though all parties hastened to state that "[their cooperation] was only for the funeral" and not the beginning of repeated collaboration', the social differences between the churches 'were allayed through the [members'] experience of joint participation.' ${ }^{14}$

As in Zambia, these popular practices in Swaziland are not sponsored by national ecumenical organisations, nor the state itself. Also, taking the economic as inseparable from the religious, the cases of popular performance discussed here are, in local vernacular, 'work', umsebenti. I conceptualise work here as an embodied adjoining of human and nonhuman action in forms of wage and non-wage labour across historical time and the life course. ${ }^{15}$ These grassroots ecumenical practices are what I call the 'work of the nation', referring to the Swazi ethno-nation constituted as part of and yet subtly distinct from the ways it is forged in kingship. Discussing the practical and symbolic associations surrounding this kind of work is not merely an ethnographic exercise. Rather, focusing on religious, cultural, and historical drivers of contemporary social organisation enable us to better situate diverse aspirations and formations of politics that are characteristic of post-colonial Southern Africa. ${ }^{16}$ Indeed, that Christianity should constitute a type of national mass or public culture

${ }^{10}$ B. Jules-Rosette, 'Grass-Roots Ecumenism', African Social Research 23 (1977), p. 186.

${ }^{11}$ See also M. Engelke, A Problem of Presence (Berkeley, University of California Press, 2007); B. Jules-Rosette, African Apostles (Ithaca: Cornell University Press, 1975); I. Mukonyora, Wandering a Gendered Wilderness (New York: Peter Lang, 2007).

${ }^{12}$ Jules-Rosette, 'Grass-roots Ecumenism', pp. 186-187.

${ }^{13}$ Jules-Rosette, 'Grass-roots Ecumenism', p. 214.

${ }^{14}$ Jules-Rosette, 'Grass-roots Ecumenism', p. 211.

${ }^{15}$ This indigenised concept I derive from my own research and others working in this ethnolinguistic region who have looked at the locally cultural and historical intersections of action, work and labour, and being-in-the-world: C. Golomski, 'Generational Inversions', African Journal of AIDS Research, 13, 4 (2014) pp. 351-359; C. Golomski, Funeral Culture: AIDS, Work and Cultural Change in an African Kingdom (under review); H. White, 'Spirit and Society', Anthropology Southern Africa, 36, 3-4 (2013) pp. 139-145; H. White, 'Outside the Dwelling of Culture', Anthropological Quarterly, 83, 3 (2010) pp. 497-518; V. Laterza, B. Forrester, and P. Mususa, 'Bringing Wood to Life', in T. Ingold and G. Palsson (eds), Biosocial Becomings (Cambridge: Cambridge University Press, 2013), pp. 162190; V. Laterza, 'Breathing Life', (PhD thesis, Cambridge University, 2012).

${ }^{16}$ J. Ferguson, 'Declarations of Dependence', Journal of the Royal Anthropological Institute, 19, 2 (2013) pp. 223-242; H. White, 'A Post-Fordist Ethnicity', Anthropological Quarterly, 85, 2 (2012) pp. 397-427; H. White, 'Custom, Normativity and Authority in South Africa', Journal of Southern 
in Swaziland does not mean that it threatens the absolute monarchial state, as the state itself operates and embodies its own type of public culture as a reified form of Swazi Culture or traditionalism. These cultural domains are more complementary, if not mutually reproductive for sociopolitical life in the Kingdom.

I take up these claims more in the conclusion, discussing how cultures of popular Christian religious practice like these might tell us something about the relationship between ecumenism and the creation of publics in the postcolony. Before doing so, I first discuss how projects aimed at forging orthodox institutional ecumenism have failed to materialise. Then I outline the more prevalent grassroots ecumenical examples of foodways, prayer, and burial cooperative participation, given their ubiquity of as part of contemporary funeral culture. These examples derived from my long-term ethnographic research in Swaziland on HIV/AIDS and cultural change beginning in 2008 where I lived with families in their homes in urban and rural areas, getting to know their relatives, neighbors, coworkers, and fellow church brethren as they relished in life's joys and faced the end of life in others' deaths ${ }^{17}$. Overall, this article demonstrates how the work of grassroots ecumenical practices, born from illness, dying and death, occasion sociocultural disruption for orthodox forms of religious institutional governance.

\section{STRUGGLES FOR INSTITUTIONAL ECUMENISM}

There are three well-established national ecumenical bodies in Swaziland-the Swaziland Conference of Churches (SCC), the Council of Swaziland Churches (CSC), and the League of African Churches (LACS) and now a fourth, the Swaziland Christian Churches United in Christ (SCCUC). Another organisation, the Church Forum, also tries to bring together churches to collaborate on issues of public health and social welfare. Despite these institutions' intertwined histories ${ }^{18}$, their leaders have faced setbacks on projects that would realise institutionally based ecumenical goals. Indeed, their worship styles, theology, and different commitments to Swazi society make these ecumenical bodies sometimes too different, at least for their leaders, to unite their respective churches.

The SCC churches, including the Nazarenes, Assemblies of God, Evangelical Church and others have historically focused on church planting and evangelising, maintaining a middle-class aspirant Protestant aesthetic, which, on the surface, may not seemingly align with the traditionalist focus of kingship. Rather, SCC churches compartmentalise their faith in order to remain close to kingship out of patriotic, ethno-nationalist sentiments. According to one religious studies scholar I interviewed in March 2011 at UNISWA, perhaps up to

African Studies, 41, 5 (2015) pp. 1005-1017; J. Hickel, Democracy as Death (Berkeley, University of California Press, 2014); S. Mnisi Weeks, 'Beyond the Traditional Courts Bill', South Africa Crime Quarterly, 35 (2011) pp. 31-40; H. West, Kupilikula (Chicago: University of Chicago Press, 2000). ${ }^{17}$ Ethnographic, document, archival, and qualitative research with households, churches, mortuaries, burial cooperatives, community judicial councils, health and social welfare NGOs, and the insurance industry was carried out in all four districts in Swaziland in July-August 2008, December 2009January 2010, August 2010-July 2011, August 2014, and May-June 2015. Brandeis University and the University of the Witwatersrand ethically cleared the research. From 2010-2011, the author was a research affiliate at the University of Swaziland (UNISWA) Department of Theology and Religious Studies.

${ }^{18}$ For more on distinctions between the three ecumenical bodies, see: C. Golomski and S. Nyawo, 'Christians' Cut', Culture, Health \& Sexuality (2017), advanced online publication. DOI: 10.1080/13691058.2016.1267409; S. Nyawo, H.L. Ndlovu, D. Nhlabatsi, and P. Mkhonta, 'The League of African Churches in Swaziland' (unpublished paper, Kwaluseni: University of Swaziland, 2011); J.B. Mzizi, 'Is Somhlolo's Dream a Scandal for Swazi Hegemony?', Missionalia, 33, 3 (2005), pp. 441-458; R.S. Kumalo (ed), Religion and Politics in Swaziland (Bloemfontein: SUN Press, 2013). 
'90\% of Nazarenes don't participate in iNcwala [the annual national ceremony of kingship] and yet their kingly loyalty is very strong.' Another member of the Evangelical Church I knew, a pastor's wife, once served as a lady-in-waiting to the Queen Mother on a month-long royal excursion to South America and the Middle East. Like the SCC, LACS is extremely loyal to kingship, but in both ideology and ritual practice. LACS undertakes the annual Pasika or iGoody event lasting each year around Easter from Wednesday to Monday and is sponsored and attended by the reigning King Mswati III and Queen Mother Ntombi Tfwala who both deliver sermons ${ }^{19}$. Kumalo notes that this relationship between LACS and the kingship is one of 'convenience and mutual benefit' given the two institutions' historical relationship ${ }^{20}$. The kingship has also tried to incorporate new religious movements of (Neo) Pentecostalism toward its traditionalist domain. For example, Swazi TV features a show on Sunday evenings called Siyadvumisa ('We praise/glorify') featuring church worship services of Pentecostal style 'ministry' churches, one at both the King and or the Queen Mother sometimes guest-appear, preach and adopt a linguistic cadence similar to glossolalic pastors of these same churches. A daughter of King Sobhuza II, Princess Lindiwe, is also the wife to the Apostle Robert Kasaro, leader of a ministry mega-church in Matsapha, and her sister Princess Ncengencenge is a regular pastor there who has preached about submission to the 'king' as both an idiom for God and a state sovereign.

In contrast to these ecumenical bodies more strongly tied to the kingship is the CSC, a group splintering from SCC between 1973-1976 that includes Catholics, Anglicans, Methodists, and other churches of the World Council of Churches. 'Besides the CSC [churches]', one religious studies scholar told me in a 2011 interview, '[non-CSC] churches are not political. The Catholics helped out students in their toyi-toyi protests, as have some Lutherans and Methodists. ${ }^{21}$ These are older churches but they are liberal and not so hypocritical as others. They have sound theological statements and honest positions on political issues.' J.B. Mzizi has argued, however, that historically the CSC has lacked "charismatic leadership that can translate their mission in creating a democratic Swaziland into an aggressive, yet Christian, programme of change ${ }^{, 22}$ on a societal level. In the line of questioning then on whether having a liberal, social justice orientation would conflict with state politics, my scholarly interviewee noted that the CSC and Swazis generally were not necessarily anti-culture, nor anti-kingship, but were instead critical of the governmentadministrative system called tinkhundla. ${ }^{23}$ These criticisms may bleed into criticisms of kingship given that tinkhundla is a decentralised system of royalist administrators, appointed by a kingly council, who oversee the country's chiefdoms and claim land, including serious

\footnotetext{
${ }^{19}$ Ndlovu, 'The Royal Easter Ritual'; Kumalo, Religion and Politics in Swaziland, pp. 9, 63, 343.

${ }^{20}$ Kumalo, Religion and Politics in Swaziland, p. 50; see also P. Cummergen, 'Zionism and Politics in Swaziland', Journal of Religion in Africa, 30, 3 (2000), pp. 370-385; B. Sundkler, Zulu Zion and some Swazi Zionists (Oxford: Clarendon Press, 1976); J. Cabrita, this issue.

${ }^{21}$ The Anglicans and Catholics also harboured ANC exiles and activists during apartheid and proposed Black Consciousness ideologies. Nhlanhla C. Dlamini, personal communication, 6 July 2014; E. Masilela, Number 43, Trelawney Park, KwaMagogo: (Claremont: David Philip, 2007), pp. $67,98$.

22 J.B. Mzizi, 'Leadership, Civil Society and Democratization in Swaziland', Development Policy Management Forum Policy Brief Series 9, (2002) Addis Ababa: Development Policy Management Forum and United Nations Economic Commission of Africa, p. 3

${ }^{23}$ R. Levin, When Sleeping Grass Awakens (Johannesburg: University of the Witwatersrand Press, 2000); M. Sihlongonyane, 'The Invisible Hand of the Royal Family in the Political Dynamics of Swaziland', African and Asian Studies, 2, 2 (2003), pp. 155-187; T. Debly, 'Culture and Resistance in Swaziland', Journal of Contemporary African Studies, 32, 3 (2014), pp. 284-301.
} 
cases of evictions, relocating cemeteries, and preventing local residents' and chiefs' burials. ${ }^{24}$ The CSC has also aligned with critical Western media stories on the royal family's consumption habits, demonstrating against Mswati's 40/40 birthday celebrations in 2008, which involved a shopping trip for his wives to Dubai. LACS, in turn, condemned CSC for their statements. These differences in state political relations tend to undercut the three ecumenical bodies' attempts to forge institutionally singular Christian projects: first, in struggles to organise and build a new National Interdenominational Church, and second to make Christianity the official state religion.

Swaziland already has a building in Lobamba called the National Church, built by King Sobhuza II in the mid-twentieth century at the request of Queen Mother Lomawa Ndwandwe, who wished 'for Christianity and Swazi Traditional Religion to be brought together and practiced by the Swazis' ${ }^{25}$. The existing National Church is heavily utilised in the national LACS ceremonies. A round, two-storied building adjacent to the Parliamentary offices and King Sobhuza II Memorial Park, Mswati remarked at the 2006 Easter ceremonies that the "current building was very old and in an unacceptable state. ${ }^{26}$ That same weekend, he pledged his support and E350,000 for the project, ${ }^{27}$ following meetings and acceptance of a proposal presentation earlier that year by a committee made up of members from SCC, CSC, LACS and SCCUC. The committee asked for the King's support in renewing and renaming the church the Swaziland Interdenominational Church, which would seat 30,000 attendees. Yet ten years later, there has been expressed disappointment from the public, the ecumenical bodies, and the King himself in that the project has yet to materialise. Construction was supposed to commence 2009 but failed to start due to what was cited in 2012 as revised design issues requested by Mswati. The original estimated construction cost of E300 million has since gone up to E1.2 billion. ${ }^{28}$

The inability of the ecumenical bodies and other elite institutions to move forward on development of the church represents some of the ways denominations as institutions make concrete or confound networks of infrastructure in both social and material forms ${ }^{29}$. Indeed, given the practical, ritual, and theological differences among the ecumenical bodies, how could a single building embody a single, unified Christian ethos in space? Kuper showed similarly how political institutions in Swaziland uneasily materialised in space according to institutions' particular politicised language and objectives in the late colonial period of the

\footnotetext{
${ }^{24}$ See the court cases of royalist-appointed chiefs and the evictions of residents at Macetjeni and KaMkhweli with cases available at the Swazi Legal Information Institute (http://www.swazilii.org/): Minister for Home Affairs and Others v Fakudze and Others (6/2002) [2002] SZSC 29 (10 June 2002); Chief Mtfuso and Another v Swaziland Government and Others (NULL) [2000] SZHC 82 (5 September 2000); Chief Mtfuso II and Another v Swaziland Government (2685/2000) [2000] SZHC 18 (13 October 2000); W. Dlamini, 'Macetjeni/KaMkhweli Opens a New Chapter', Times of Swaziland (2010) November 22; Golomski, Funeral Culture

${ }^{25}$ Kumalo, Religion and Politics in Swaziland, p. 57. J. Cabrita (this issue) discusses Sobhuza's 1939 institutional formation of the "National Swazi Church" which ecumenically united Ethiopian churches like the Independent Methodist Church and others, later renamed the United Christian Church of Africa (UCAA) in 1944 to draw in more diaspora Swazi. It eventually disbanded in 1950 with the nationalistic and popular rise of Zionist-oriented LACS.

${ }^{26}$ No author, 'King Pledges E350,000 for New National Church', Swazi Times (2006) April 18

${ }^{27}$ The King expressed disappointment that by the end of the ceremony, 20,000 attendees contributed E7,084.

${ }^{28}$ N. Mathunjwa, 'Five Years Later, No New Church', Times of Swaziland (2012) July 29; N. Shongwe, 'E1.2 Billion for National Church Construction', Times of Swaziland (2014) August 18 ${ }^{29}$ C. Handman and M. Opas, 'Introduction: Institutions, Infrastructures, and Religious Sociality', Ethnos (forthcoming)
} 
1960s, using contested examples of building Parliament in traditionalist Lobamba versus white-centric Mbabane and re-locating the trials against royalist political oppositionist Prince Dumisa and others of the Ngwane National Liberatory Congress also to Lobamba. ${ }^{30}$ In these cases royalists strove to consolidate power in spaces that were religiously advantageous to them as traditionalists and under the guise of ethno-national dis-unity thereby shutting out political opposition in the process. The consolidation of the original National Church in the same colonial period under royalists' guise speak similarly to their politics of the time, but the contemporary construction problems of this new inter-denominational space represents a disrupted attempt at institutional ecumenism given the bureaucracy of leadership, fundraising, development and promotional materials needed literally to get the project off the ground.

The second major recent struggle of orthodox institutional ecumenism has been church organisations' leaders and elites' attempts to constitutionally re-inscribe Swaziland as an official Christian nation. Since 1973, Swaziland had operated without a constitution following a royal decree by Sobhuza II to suspend the colonially derived Westminster style constitution shepherded in by the British at Independence in 1968. Sobhuza II deemed such a governing document to be culturally and politically un-Swazi. Facing mounting international pressure over the next several decades from foreign governments and multi-lateral agencies involved in development projects, Mswati commissioned a committee in the early 2000s to solidify would become the country's new constitution. A draft of this document included a section that explicitly stated that Christianity be the official state religion, bolstered by historical interpretations of King Somhlolo's vision of accepting Christianity prior to Western missionaries' arrival. However, the final 2004 legislated version of the constitution removed the Christian clause, an edit approved by Mswati himself. ${ }^{31}$

In 2010, several members of Parliament (MPs), along with church organisation leaders, tried again to insert an institutional type of ecumenism at the state level by proposing the formation of a group called the Parliamentary Christian Association. Yet a majority of MPs had the opinion that they already identified as religious subjects and were concerned for how such a politically affiliated association would appear to non-Christian Swazi citizens. Some MPs expressed concern because of their simultaneous adherence to Swazi 'traditional religion' given that they were effectively working for the king himself as a lower level of government in this absolute monarchy. Concerns also arose on how to oversee financial transactions of such an association, and how an association might engender divisions within the House of Parliament - a very real concern given the divisiveness already present among some of the ecumenical bodies' leaders, even if the proposed association's proponents claimed it would bond together many of the churches in the country. In a Times of Swaziland newspaper article on the matter, MP Robert Magongo, citing the religious visions of King Somhlolo, said Parliament should choose to uphold Christianity for its own 'great benefit.'

\footnotetext{
${ }^{30}$ H. Kuper, 'The Language of Sites in the Politics of Space', American Anthropologist, 74, 3 (1972), pp. 411-425; Levin, When Sleeping Grass Awakens

${ }^{31}$ Mzizi, 'Is Somhlolo's Vision a Scandal'; Kumalo, Religion and Politics in Swaziland, pp. 232-298;

B. Dlamini, 'Did Somhlolo's Dream Have Anything to do with the Bible?' Times of Swaziland (1998) February 8; B.S. Dlamini, 'Sobhuza I', in Dictionary of African Biography, vol. 6, E. Akyeampong and H.L. Gates Jr. (eds), (Oxford: Oxford University Press, 2012), pp. 424-425; N. Nyawo, 'Theological Education in Swaziland', in The National Consultation on Theological Education in Swaziland, J.B. Mzizi (ed), (Mbabane: Ministry of Education, 1994), pp. 26-30; H. Kuper, Sobhuza II (New York: Africana Publishing Company, 1978)
} 
Another MP, Peter Ngwenya, said the House was being bullied into joining such an association and that its advocates should rather 'go back to their churches' ${ }^{32}$.

In an interview on UNISWA's campus in May 2011, religious studies scholar Hebron L. Ndlovu explained to me that Mswati turned down the proposal because it would contradict an aspect of the king's nationalist persona: 'The king is a king by his people, but people are Christian, ancestral, Bahai and increasingly Muslim, all by both birth and naturalisation. They are all Swazis, so then there is a contradiction in nationhood if we call them all Christians [only]... In my view, the king was protecting Swazi Traditional Religion in overruling the Christian contingent'. Indeed, such legislated declarations about a singular state religion may also transgress international human rights accords dealing with issues of religious freedom and running the risk of souring relations between the state and religious minorities, as Phiri describes for Muslims in Zambia ${ }^{33}$. Not only could this move be a setback for state public relations, but could also engender further divisions among state and religious elites. Mswati and the majority of MPs were ultimately against claiming an official Christian national identity to save face for the state's strong traditionalist brand. Interestingly here, kingly state traditionalism aimed to accommodate citizens' religious diversity and overrode a patently Christian nationalism. Despite being championed by major church organisational leaders, this attempt at legislating religious identity did not resonate with the political representatives of the country's majority Christian citizens. 'It was best to avoid it altogether', said MP Peter Ngwenya, for if these few Christian leaders got their way, 'some will want a halaal association' next. ${ }^{34}$

These cases of the new interdenominational national church and the Christian clause in the 2005 constitution show the difficulties elites and orthodox ecumenical leaders have had in Swaziland to reify Christianity as an entity beyond the everyday religious practice of ordinary citizens. I signpost the word reify and reification intentionally here, taking cue from Hannah Arendt ${ }^{35}$, and explore it more closely in the conclusion, because it can lead us to consider why ordinary citizens might resist more permanent articulations of Christianity in favor of organic, re-workable articulations that are still Christian, formative of publics, and deeply committed to social memory. Even if grassroots ecumenical practices concern the production of deathways, which I describe next, these practices are powerfully animated by what Arendt calls the 'living spirit' ${ }^{36}$ of ordinary citizens' religious imperatives.

\section{WORK OF THE NATION: GRASSROOTS ECUMENICAL FUNERARY PRACTICES}

\section{Funerary Work: Foodways and Prayer}

Turning off the ignition and alighting from her white Pajero, my informant LaGija's sister Zinhle hauled out three large buckets of KFC chicken in plastic bags. We were at the funeral for LaGija's sister-in-law Esther. We had just pulled up to Esther's parents' pine treeringed countryside homestead around 6:30 in the evening, a few hours before the night vigil. LaGija came early as a daughter-in-law, makoti, to prepare for the next morning's feast, along with a dozen affinal women related to Esther's family. We also brought several loaves of brown bread and bags of brown sugar from the Spar supermarket, victuals to be used in the night vigil tea service taking place between 3 and 4 in the morning among sermons and

\footnotetext{
${ }^{32}$ S. Sukati, 'MPs Say No to Formation of Christian Association', Times of Swaziland (2010) August 26

${ }^{33}$ I.A. Phiri, 'President Frederick Chiluba and Zambia', in Evangelical Democracy and Christianity in Africa, T.O. Ranger (ed), (Oxford: Oxford University Press, 2008), pp. 95-129.

${ }^{34}$ Sukati, 'MPs Say No'

${ }^{35} \mathrm{H}$. Arendt, The Human Condition (Chicago: University of Chicago Press, 1958) pp. 167ff, $95 f$

${ }^{36}$ Arendt, The Human Condition, p. 95
} 
preaching. Besides Zinhle, seven of LaGija's nine adult siblings, as well as her mother and a maternal aunt eventually came to the funeral to show support and pay condolences as a family and members of their ministry church. Three other members of this church also attended and sat nearby LaGija's family. Esther and her parents were Anglican, and the retinue of pastors emceeing the event came from several denominations-Anglican, Wesleyan, Catholic ('Roma') - who were invited by members of the larger extended family. A large morning meal has become compulsory. It comes in many varieties, given the unexpected assortment of donations like bread, onions, cookies, or KFC brought by attendees. In order to feed the diverse crowd that make up most funerals like Esther's, this big meal has to be satisfying after a long and often-cold night spent singing in a tent.

Food purchase, preparation, service and feeding are constitutive of what I see to be one part of the major grassroots ecumenical work of funerals that diverse Christian people collectively undertake in Swaziland. ${ }^{37}$ Other significant social and material actions making up the grander production of funerals, imingcwabo or imisebenti (plural of umsebenti, or 'work'), include event organisation, mobile phone communication, tent and chair rental and site set-up, transportation, grave-digging, sermons, singing and prayer, all meant to create a funeral that is dignified ${ }^{38}$, one that is said to be well-prepared or well-sorted, kulunga kahle. The efforts put into these weekly social events are multiple, at once economic, sociocultural, and ecumenical, and achieved through a Christian ethos that aims for toleration and acceptance of denominational differences among attendees where other social differences might make civility difficult. ${ }^{39}$

The loosely ecumenical dimension of foodways coheres around processes of multiple Christian actors' and groups' donations of materials, effort, and time before and during the event. A facet of this aesthetic and social quality of funerals being well-prepared is that they are well-attended, kubakhona bonke: the more people who attend and help out, the more dignified the event is overall. For example, working side by side with affinal relatives, and amid the gendered auspices of a generalised antagonism between daughters (in-law) and mothers (in-law), LaGija's service and food donations were welcome, because they created a type of Christian event for which Esther's families aspired. Indeed, funerals are accomplished precisely because of the cooperative work of many distinct groups of persons who identify as Christian, be they family, friends, co-workers, and, importantly, members of burial cooperatives and other churches. Interestingly, conflicts Swazi religious studies scholars Nyawo, Mhlobo and Mpapane identify with this collective work arise between Christians and non-Christian traditionalists or self-identified Christians who deploy vernacular forms of funerary practice. According to these scholars, 'Christian leaders sometimes face problems when they try to help fellow believers who hold onto deep cultural beliefs that sometimes

\footnotetext{
${ }^{37}$ The contemporary significance of this work derives in part from funerals' regularity due to HIV/AIDS. 85 out of 94 household respondents I surveyed between February and May 2011 across five rural and urban communities told me that funerals were the most common life cycle rite today, reporting that they attended an average of five to six per month. While 29 told me they were unsure, the rest estimated that almost $40 \%$ of those funerals they attended in the past six months were for deaths due to HIV/AIDS.

${ }^{38}$ On the value of dignity in context, see: C. Golomski, 'Urban Cemeteries in Swaziland', Anthropology Southern Africa, 38, 3-4 (2015), pp. 360-371; T.O. Ranger, 'Dignifying Death', Journal of Religion in Africa, 34, 1-2 (2004), pp. 110-144; A. von Schnitzler, 'Performing Dignity', American Ethnologist, 41, 2 (2014), pp. 336-350; R. Werbner, Divination's Grasp, (Bloomington: Indiana University Press, 2015).

${ }^{39}$ D. Durham and F. Klaits, 'Funerals and the Public Space of Sentiment in Botswana', Journal of Southern African Studies, 28, 4 (2002), pp. 777-795; F. Klaits, Death in a Church of Life (Berkeley: University of California Press, 2010)
} 
clash with what religious leaders teach. These challenges are often seen during the times when Christians feel the need to perform rituals, for example, ... at death.' 40 Such 'rituals' and 'cultural beliefs' include what are considered non-Christian 'traditional' funerary forms like widows shaving their hair after the burial, burying the dead with his or her clothing items, and ancestral veneration at homestead cattle pens during processions to the gravesite. ${ }^{41}$

While ritual differences are evident across the religious spectrum of 'traditional' to Christian, accommodations are made in situ to allow for a diversity of worship and prayer practices, imithandazo. Indeed, along with food production, prayer is a second major form of grassroots ecumenical work. While not categorically a type of 'work' in siSwati as umsebenti, the intensity, breadth, and regularity of prayer and prayer sessions in the home, schools, clinics, parks, and the workplace make it a ubiquitous public Christian phenomenon. Christians' organisational leaders call for their followers to care for the dying and 'the sick, including those living with HIV and AIDS. This involves praying for the sick, organizing for someone to visit them to comfort them and to encourage their faith... [and] can help with home chores such as cleaning and cooking. ${ }^{42}$ This call for prayerful intervention supplements the interventions of foodways and generalised caregiving and echoes what most people see Christians as doing anyway in their own communities. In a household survey of 94 respondents I conducted across five urban and rural communities in 2011, 71 reported that Christians care for the sick and dying, with 50 telling me and my research assistants that prayer was the most common intervention for ill persons, followed by in-home visitations (42), bringing food (10) and aiding in mourning (4). ${ }^{43}$ A group of Sunday school teachers I interviewed at a rural Free Evangelical Church in the Shiselweni in February 2011 similarly stated that Christians provided support at the end of life, categorising these interventions as 'spiritual' and 'physical.' 'For physical things,' they said, 'we give sugar, soap, candles and visit. We go to pray, we go to the funeral and sing for those who are bereaved. [The bereaved] can also receive money from the church and some will make the food and bring money. The spiritual things they get help with is the Word of God... by praying, studying the bible, and sharing with others.'

The Word (of God), livi leNkosi, is a profound spiritual entity cultivated by Christians in prayer across the ecumenical spectrum. The aesthetic, embodied and healing forms in which the Word materialises vary across churches according to their particular prayer or ritual practices ${ }^{44}$, and these practices are often the focal point for intra-Christian comparison and differentiation. Despite the often-unavoidable critical comparison rendered by people of different churches at funerals themselves, there is very little outright rejection of any single prayer or ritual style. Rather, styles combine, or different church groups assent to listen to,

\footnotetext{
${ }^{40}$ Nyawo, S., P. Mhlobo, and Z. Mpapane, Religious Education in Context (Manzini: MacMillan BOLESWA, 2009), p. 163.

${ }^{41}$ Nyawo, Mhlobo, and Mpapane, Religious Education, pp. 61-62; C. Golomski, Funeral Culture; H. Kuper, An African Aristocracy (Oxford: Oxford University Press, 1980); P. Kasenene, Swazi Traditional Religion and Society (Mbabane: Webster's, 1993).

${ }^{42}$ Nyawo, Mhlobo, and Mpapane, Religious Education, p. 163.

${ }^{43}$ This randomized cluster-sample survey was done in three urban neighborhoods around Manzini and Matsapha and two rural areas, one in southern Hhohho and one in central Shiselweni. Research assistants who were resident at two urban sites and one rural site helped me in note-taking and question-asking. Out of the 100 householders age 18 or older sampled, 94 agreed to participate. With the aid of research assistants at three of the sites, we asked questions pertaining to demographics, work-related migration, remittances, religiosity, participation in burial cooperatives, insurance, and life cycle rites, and general perceptions of the effects of HIV/AIDS in their communities.

${ }^{44}$ Engelke, A Problem of Presence; B. Meyer, 'Aesthetics of Persuasion', South Atlantic Quarterly, 109, 4 (2010), pp. 741-763.
} 
observe, and accommodate others. As Jules-Rosette found in Zambia for the Maranke and Masowe, or as Werbner and Kealotswe found in Botswana for other new churches ${ }^{45}$, funerals in Swaziland's age of HIV/AIDS are events where mutually sharing through prayer enacts Christian objectives of caring for others that are also ecumenical, despite the wide variation in form that prayer takes.

Take for example a funeral I attended in October 2010 with an informant Lucky and his wife LaMsetfwa in the Manzini district. The funeral was for LaMsetfwa's grandmother Mbandlile, one of her grandfather's 13 wives. With a 'family like a village,' Lucky told me, Mbandlile's descendants affiliated to many different Christian churches. At this event, the majority of attendees belonged to ministry churches and Zionist Jerikho churches ${ }^{46}$, which in aesthetic and socio-economic terms seem to be wildly incongruous. Jerikho, a LACS church of local origin, is 'married to kingship', bayaganwa nenkosi, in its long history of traditionalist affiliation with the state, deriving its membership from mainly rural areas and lower socioeconomic strata. Jerikho is marked by ritual practices of spiritual possession and members' brightly colored robes. In contrast, ministries, like other (Neo) Pentecostal churches, emphasise glossolalia, tithing, the prosperity gospel, and salvific self-focused narratives of being 'born again'; members tend to wear business casual attire to worship services. Despite these differences, the two Christian groups come together in funerals to shore up dignity for the deceased and bereaved as a shared objective.

A practical way to do so was to openly recognise and be kind to others at funerals. When we arrived, Lucky asked to share another beer before he wandered off and I went with LaMsetfwa to the tent to listen to the night vigil service. Accompanied by a teenager on an electric keyboard, a team of pastors from a ministry church' emceed the service, orchestrating a series of speeches and songs. Many of the sermons emphasised a 'homecoming', a metaphor for the end of life's path and the site of the deceased person's (spiritual) postmortem location. 'God wishes for us to return home [in death]', one ministry pastor explained, 'whether at work, at school, or at home, God is with us as Christians. Even Zionists are Christians, and, in fact, even these Jerikho here are Christian too!' The Zionists in the tent applauded amid other attendees' support for the statement. Later, a man from the audience echoed the pastor's sentiments: 'like the pastor said, we have Zionists here too. Zionists are redeemed [kusindzisa, saved or born again] too!'

These grassroots ecumenical statements of recognition and attendees' appreciation for them were clear, as was Jules-Rosette's point about 'asymmetry' 47 or hierarchy amongst Christians and their prayer practices in the interdependent production of the funeral. Around 2:30 in the morning, a Zionist woman stood to read a passage from the book of Job, but before she could start, a male associate of one of the ministry churches stood up and took the microphone away, saying with some urgency, 'now we are going to sing.' The woman sat down and a ministry pastor began to chant, 'ngcwele, ngcwele, ngcwele, moya oyingcwele' ('Holy, holy, holy, Holy Spirit'). The almost two hundred people in the tent grew into a

${ }^{45}$ R. Werbner, 'Coming Together in Christian Wakes: Ecumenical Caring, Consoling Words, and Dissonance', paper presented at the African Studies Association meeting, San Diego, 19 November 2015; O. Kealotswe, 'The Role of Mulindelo/Motletelo as an Important Aspect of Ecumenism in the African Independent Churches in Botswana', paper presented at the 'Ecumenical Predicaments and Religious Pluralism' conference, University of Botswana, 9 March 2015; Klaits, Death in a Church of Life.

${ }^{46} \mathrm{C}$. Golomski, 'Risk, Mistake and Generational Contest in Bodily Rituals of Swazi Jerikho Zionism', Journal of Contemporary Religion 31, 3 (2016): 351-364; A. Fogelqvist, The Red Dressed Zionists (Uppsala: Acta Uppsala Universitaet, 1987), H.L. Ndlovu, 'The Royal Easter Ritual'; J. Cabrita, this issue.

${ }^{47}$ Jules-Rosette, ' Grass-Roots Ecumenism', p. 214. 
collective swell of voices until it was cacophonous, and the pastor and several others slipped from speaking in a second-person siSwati dialogue with God to speaking in tongues. This continued for at least three minutes until a group of Zionists returned to the 'holy' chant. As the pastor's own glossolalia diminished, so did the rest of the attendees', and the tent came to a lull. The pastor then handed the microphone to his associate, returning it to the woman who was interrupted.

In this example, the predominance of the ministry churches' glossolalic prayer and their leaders' charismatic directorship is evident, despite the event drawing in diverse Christians. Not organised or emceed by Zionists, who probably made up more than half of the funeral attendees, several of the ministry pastors and lay non-Zionist preachers made comments shoring up inclusivity at the event on the grounds of shared Christian identity. Specifically, this took shape in Pentecostal terms, in their particular cultural language of being 'saved' or born-again' and recognising that 'even Zionists' might be 'saved' like they were. The occasion of the pastoral associate usurping the Zionist woman's exegesis shows a gendered and asymmetrically ecumenical moment, where Pentecostal glossolalia took center stage through the ministry pastor's lead. The swelling of spirited voices is not uncommon in either church at regular Sunday worship service-there are usually a few instances of collective glossolalia in ministry church services, and Jerikho Zionists open and close their worship services with a march-cum-run that drives some members into intensely verbalised spiritual possession. Yet this was the only funeral I attended in my research that such a glossolalic moment occurred, suggesting denominational-ritual predominance of Pentecostal prayer over other churches' prayer. ${ }^{48}$ Prayers like these, along with foodways then are potent forms of religious-ritual work open to all who variably identify as Christian in the space of multidenominational funerals.

\section{The Cooperative Gospel: Christian Burial Cooperatives and Mediated Formalisation}

Occurring before the morning funeral feast and after the all-night prayer is burial, umngcwabo, the third form of grassroots ecumenical work I discuss here. Burial itself is an expansive production. In the short term, sometime during or just before the funeral a group of men dig the grave itself and are usually compensated with some form of food or drink like home-brewed emahewu, maize meal drink, tjwala, fruit-based alcohol, or umcombotsi, maize meal beer. In the long term, women, several people told me, invest more time and money in burial cooperatives to pay for funerals ${ }^{49}$. In Swaziland, burial cooperatives, bomasingcwabisane ('let us bury one another') originated in the mid-twentieth century when women whose husbands and families were part of regional migrant labor circuits began to pool money for funerals. ${ }^{50}$ These organisations collect money through members' monthly fees to pay out in claims on members' and dependents' deaths and include cash and material goods. Most people I knew belonged to several cooperatives in addition to subscribing to formal life insurance policies, combining the two as a way to maximise coverage. This way, they could better assure a dignified funeral for their extended social networks of relatives and social dependents.

Cooperatives are particularly ecumenical in the sense discussed here first because, even if they are associated with a single church, they can include members who are not

\footnotetext{
${ }^{48}$ Golomski, Funeral Culture

${ }^{49}$ This continues what was found for cooperatives in the 1980s, which were by and large run by women, limiting membership to 'respectable,' and 'responsible' Christian women. S. Kappers, 'Sitanini - Let's Help Each Other', in Scenes of Change, H. Tieleman (ed), (Leiden: African Studies Center, 1988), pp. 163-186.

${ }^{50}$ Kappers, 'Sitanini'; Golomski, Funeral Culture; H. Kuper and S. Kaplan, 'Voluntary Associations in an Urban Township', African Studies, 3, 4 (1945), pp. 178-186.
} 
affiliated with that same church. This has long been the case, as Kappers describes for one group at Logoba in the 1980s called Sibane Sabomake ('Light of Women'), which had members from Anglican, Methodist, Zionist, Catholic and African Methodist Episcopal churches $^{51}$. Second, these cooperatives are ecumenical because they tend to take on a broadly Christian ethos in terms of their organisational objectives, diverse Christian membership, and have increasingly branded themselves as Christian in the context of state-driven changes in the financial services sector. In contrast to several new life insurance companies recently opened in the Kingdom, which brand themselves using Swazi Traditional religious aesthetics usually associated with the kingship, ${ }^{52}$ Christianity's dissemination in Swaziland since the nineteenth-century makes equally potent the symbolism of light, firmament, praying hands, and moralised compounded phrases like 'we wake each other up' and 'raise up.' Seeing that companies made death a big business to attract consumers, several cooperatives I documented shored up rhetorics of Christian social solidarity and identity as a way to distinguish themselves and mediate state requests to formalise as registered entities with the Ministry of Home Affairs.

Zenzeleni is a good example of this mediated formalisation. Meaning, 'doing it for others and ourselves', it is a women-centric cooperative holding its meetings in the former convent on the Catholic church grounds adjacent to the Cathedral in Manzini. They began as a small group in the 1990s and meet regularly on a monthly basis. As of 2012 there were about 400 contributing members providing coverage for funeral expenses to nearly 5,500 people as dependents and beneficiaries. Members record monthly contributions in pink booklets marked on by a crucifix after paying an E500 joining fee. This qualifies members to receive a coffin, use of a vehicle to transport bodies, a machine to lower the body into the earth, a food hamper, and members' labor to help others at the funeral, like LiGija, produce the feast. Like the members of other cooperatives I spoke with, Zenzeleni members and chairwomen appreciate the Christian organisation's material contributions and personable sharing in the moral project of burial.

In an interview with the chairwomen of the cooperative, I was told that Zenzeleni was special because they allowed anyone to participate. One need not be a particular member of the Catholic church where they held their meetings, nor did one need to exclude particular persons from coverage. Indeed, one of formal life insurance's stipulations is that the policyholder and the dependent or beneficiary be of some legal or blood relationship to one another. The treasurer explained to me that members could sign up anyone as a dependent, including even a hypothetical unrelated 'poor old neighbor man,' which for members evidenced a Christian commitment to show God's love by preparing for others' burial. In a similar case, Mildred 'Shorty' Khumalo, the lead caregiver at Shiselweni Reformed Church Home-based Care (SHBC) for people living with HIV/AIDS ${ }^{53}$, told me in a May 2011 interview that their cooperative of 56 members permitted the inclusion of up to six children unrelated to the member.

During the meeting following the interview at Zenzeleni, the chairwomen discussed with members how as part of their formalisation process, they were expanding their resources by purchasing a vacant mortuary. Following a budgetary assessment, the board members faced the prospect of going to a bank for a loan. While deciding to register as a company given the hurdles of doing so as an NGO - 'it seemed a futile endeavor doing it as an NGO',

\footnotetext{
${ }^{51}$ Kappers, 'Sitanini', p. 182.

${ }^{52}$ Golomski, Funeral Culture

${ }^{53}$ For more on this Christian caregiving organisation, see: R. Root and A. van Wyngaard, 'Free
} Love', Global Public Health, 6, suppl. 2 (2011), pp. S174-S191; R. Root, A. van Wyngaard, and A. Whiteside, 'Reckoning HIV/AIDS Care', African Journal of AIDS Research, 14, 3 (2015), pp. 265274. 
explained the vice president - and the personal help that the secretary received from her former student who worked at a bank, the board collectively decided to fundraise within the cooperative rather than going for a loan. 'The problem with the bank,' the treasurer explained, 'is that [the bank] needs a proper business plan and the repayment they have for us is a certain fixed amount with interest which we might not be able to have every month. What about paying out E150 per head towards the project to avoid going to the bank? If everyone agrees to this, let us be Christians and abide by our agreements.' The some 150 members shouted consent, clapping in agreement to the suggested payment schedule of E50 per month for three months. Here, the cooperative chose to indebt themselves to each other in bonds of Christian solidarity, rather than to a financial institution in order to materialise their organisational promise of making dignified funerals.

Zenzeleni and a few other more established cooperatives I documented, including those of workers' unions, were sagacious when it came to organisational politics vis-a-vis state formalisation requirements. Like Zenzeleni, other cooperatives sought to finance themselves in-house and avoid what they saw to be predatory companies and the state's surreptitious mismanagement. Yet the work of most cooperatives operated outside of such concerns as they were smaller-scale and not a site of direct state intrusion. They were more concerned with getting by on a barer life terrain, to feed their families through hard work. At a neighborhood care point opened by SHBC outside of Nhlangano, I met a widow in May 2011 who came daily to guide a group of orphaned and vulnerable children there for their free lunch. Wearing a black pinafore and a few black cloth and dried grass mourning ropes, tincotfo, she quietly told me how she belonged to a cooperative, a small group of about 30 women whose meager contributions of E10 per month would guarantee a payout of E500 per death-'not enough for a coffin even', she admitted. With their contributions, derived from selling emagwinya fat cakes, cookies, and bananas grown in their own yards, the group bought dishes to collectively use in funerary foodways.

Examining burial cooperatives, popular prayer practices, and ritual foodways as major forms of everyday funerary work shows how a kind of grassroots ecumenism is a moral imperative for ordinary people in Swaziland as both self-identified Christians and as citizens of a nation-state in a particular political-economic and historical context. This imperative, embodied in a will to produce dignified funerals, materialised in the short- and long-term collaborative efforts of multiple actors - relatives, neighbors, coworkers, brethren - who belonged to a variety of churches across the denominational spectrum. Within spaces of funerary preparation and production, and on more or less agreeable terms, actors negotiated socio-economic and symbolic asymmetries indicative of their different Christian churches' positions within contemporary Swazi society.

\section{THE 'GRASS' IN 'GRASSROOTS': CHRISTIAN PUBLIC CULTURE}

'Christian public culture' in the way Harri Englund proposes it, can be an initially useful term to capture some of the sociopolitical and religious dynamics discussed here, but may be expanded in considering how dynamics are shaped beyond religious institutions. He identifies a public as 'an audience whose members are not known to those who address it in order to make claims' and that 'a public addressed is a public constituted. ${ }^{54}$ Although this does clarify one usage, it introduces a shortfall in knowledge of those addressed. Below I take up Hannah Arendt's usage of the term public vis-à-vis notions of actors' and addressees' visibility and appearance. As a popular religion, Christianity is crucial for understanding public culture in Africa because (Christian) citizens' 'embodied, deeply felt experiences can

\footnotetext{
${ }^{54}$ Englund, 'Rethinking African Christianities', pp. 8-9.
} 
be represented as co-existent with instances of deliberative and critical reason' ${ }^{55}$ that intertwine political and religious domains. Taking a theoretical risk here, I want to interrogate this duality of embodied religious experiences and 'deliberative and critical reason', for if we read it against other accounts of how publics come into being in Southern Africa, we may be occluding the unique process of politics involved in grassroots ecumenism.

Indeed, to see this process clearly, we need to comprehend the tension between popular grassroots ecumenical religious practices and certain attempts of orthodox ecumenical institutions. Their attempt to grasp onto popular practices exposes a critical process in the making of publics that Arendt describes in The Human Condition. Arendt introduces the concept of the space of appearance, a contingent but viable and recurring zone of social formation that renders a group visible to itself and others as a public. Through action and speech, people actualise themselves as discrete social entities, portending political and moral recognition. Groups are able to manifest and wield power in this space, which remains in potentia and reemerges in future moments of collective appearance. Visibility to oneself and others is productive for both social memory and history. Arendt describes this process in quite telling terms: 'Without remembrance and without the reification which remembrance needs for its own fulfillment, ...the living activities of action, speech, and thought would lose their reality at the end of each process [of public appearance] and disappear as though they never had been. The materialization they have to undergo in order to remain in the world at all is paid for in that always the "dead letter" replaces something which grew out of and for a fleeting moment indeed existed as the "living spirit.", 56

For Arendt, publics are made and remade through humans' actionable imperatives and their co-presence in space-time. In a Christian cultural context, thought and action and their embodied articulations as religious experience may constitute what she provocatively calls the 'living spirit' of a group of people in the world. That spirit, the animacy of a group of acting persons, though, may become something more permanent, more 'tangible' ${ }^{57}$ as when thoughts are written down as poetry, or, in the cases discussed here, the human voice divines the Word's presence in funerary prayer, or salt is added to boiled meat at a funeral feast. This transformative process from a collection of elements to something tangibly stable, consumable, and memorable, is one Arendt calls 'reification.' Metaphorically too, as quoted above, it somehow produces something that is 'dead' once it is reified.

It is in this metaphor that we might see why orthodox institutional ecumenical organisations struggle to achieve their ideological aims of Christian unity in Swaziland. The living spirit of contemporary funerary work is, perhaps, not something ordinary citizens feel should be arrested or remembered in a uniform way. The Christian public they form each weekend is more fluid, negotiable, and open to aesthetic interpretation in the variable experiences of prayer and embodiment of the Word, of tasting and appreciating kinds of food and drink at funeral feasts, of playing a monetary part in a cooperative's contribution to get a coffin to the night vigil and into the ground. Focused on death, these are practices aimed to enliven the bereaved, kuphilisa, and to push the dead into the afterlife. Of course, such practices do get patterned over time. Burial cooperatives have by-laws. There is a relatively standard funerary fare menu. Certain bible verses get quoted and re-quoted to inure church members to the grief of loss. Are these not also reifications and highly productive in and for a public as memory?

\footnotetext{
${ }^{55}$ Englund, 'Rethinking African Christianities', p. 8.

${ }^{56}$ Arendt, The Human Condition, p. 95.

${ }^{57}$ Arendt, The Human Condition, pp. 76, 90, 95.
} 
They may be. Yet groups like SCC, LACS, CSC, SCUCC and others are challenged, as I showed, by wanting to consolidate aspects of the contemporary Christian ethos institutionally in a way that may conflate uniformity with unity. The latter is what makes ecumenism so powerfully inclusionary, whereas the former makes it institutionally exclusionary. This conflation attempts to carry the 'living spirit' too far into the realm of 'deliberate or critical reason,' to return to Englund's terms, where what it means to be Christian and for whom becomes uncomfortably in-scripted. This interpretation of the Swazi case, aligns too with a prevailing interpretation of (Christian) funerals in Southern Africa by Durham and Klaits, who write that funerals are political in that they produce public civility through sentiment-laden dynamics of mutuality, rather than through critical lines of individuated discursive rationality. ${ }^{58}$ In their argument, sentiment need not and perhaps cannot be expunged from reasoned political exchange in the public sphere. The sentimental, phenomenological immensity of funerary work, variably valued as Christian is what bears forth a Christian public that nevertheless resists what the state or orthodox ecumenical organisations claim as ideological unity reified as uniformity.

In Swaziland too, politics cannot be separated from religion, whether it be Swazi Traditional Religion or these multifarious forms of Christianity that combine, synergise, or uneasily co-exist alongside one another. Taking a look at everyday forms of funerary work that majority citizens undertake on weekly bases shows how a grassroots ecumenical sentiment constitutes a public in, Arendt's terms; that is, a public that involves citizens' in situ representations and renegotiations of moral imperatives. Producing a dignified funeral is a complex endeavor, one accomplished through a staggering number of actors, investments, and mobilities, and yet is something seemingly pulled off more easily each weekend than getting consensus on projects among ecumenical organisations' leaders and religious elites. Contemporary grassroots ecumenism in Swaziland appears to be stronger than orthodox institutional ecumenism, and moralised normativity extending across societal differences emerges not from conventional forms of political authority, but citizens' everyday religious practices of living and dying.

Finally, the symbol of grass in our consideration of grassroots ecumenism works well in this approach and particular field-site. The last critical social science monograph on Swaziland written by Levin is titled When the Sleeping Grass Awakens. The 'grass' in this critical history of royalist land possession and sociocultural hegemony represents ordinary Swazi, who under the 'cult of personality' of Sobhuza II were persuaded into acceptance of the political status quo as the Kingdom emerged from colonialism in the 1960s. From Levin's standpoint, revealing the machinations of royalists' political economy in keeping ordinary Swazis oppressed would vivify aspirations for a more democratically inclusive society. To this critical account, we must see how Christianity too constitutes the grassroots, as a rhetorical source of politics and religion as politics. The grassroots is also a symbol of what it means to be at once Christian and Swazi: it is the lutindzi grass that re-awakens seasonally in the way women pluck the root from the sheath when harvesting it for weaving and encouraging it to regrow; it is the grass used to make and house the prestige item of freerange homestead chickens in tilulu baskets; and it is the materials used to make emacansi grass-mats to wrap up or inter with the dead at funerals like those of Esther, LaMsetfwa's grandmother, and other Swazi Christians nationals.

${ }^{58}$ Durham and Klaits, 'Funerals and the Public Space of Sentiment' 